\title{
Kajian Peningkatan Produktivitas Polikultur Pada Karamba Jaring Apung di Waduk Cirata dengan Pemanfaatan Teknologi Aerasi
}

\author{
The Study of Increasing Productivity for Floating Net Cage Polyculture in Cirata Reservoir \\ By Utilization of Aeration Technology
}

\author{
Herman Hamdani ${ }^{1}$, Perdana Putra Kelana ${ }^{2}$, Irfan Zidni ${ }^{1}$ \\ ${ }^{1}$ Dosen Tetap Prodi Perikanan Universitas Padjadjaran \\ 2 Dosen Magang Prodi Perikanan Universitas Padjadjaran \\ Email : hamdani_herman@yahoo.com
}

\begin{abstract}
Abstrak
Karamba Jaring Apung (KJA) merupakan salah satu metode dalam kegiatan budidaya ikan di perairan umum seperti Waduk Cirata. Masalah yang umum dihadapi oleh pembudidaya ikan KJA di Waduk Cirata yaitu rendahnya konsentrasi oksigen di lokasi tersebut, sehingga akan berpengaruh secara langsung terhadap kehidupan ikan-ikan yang dibudidayakan. Rendahnya oksigen akan menyebabkan rendahnya laju pertumbuhan yang tentunya akan menurunkan produktivitas. Objek penelitian ini adalah produktivitas ikan bawal dan nila yang dibudidayaka secara polikultur dalam KJA di Waduk Cirata. Penelitian ini dilakukan selama 10 minggu dengan metode experimental yang menggunkanan 2 perlakuan yaitu KJA dengan airasi dan KJA tanpa aerasi. Adapun parameter yang diukur adalah oksigen terlarut (DO), amonia bebas $\left(\mathrm{NH}_{3}\right)$, suhu, pH dan bobot ikan. Konsentrasi DO rata-rata pada KJA dengan aerasi lebih tinggi 8,26\% dibandingkan KJA tanpa aerasi. Berdasarkan hasil analisis uji t, produktivitas KJA dengan menggunakan teknologi aerasi memberikan hasil produktivitas lebih baik bandingkan dengan tanpa menggunakan aerasi. Produktivitas ratarata KJA dengan aerasi sebesar $11,47 \mathrm{Kg} / \mathrm{m}^{3}$, sedangkan KJA tanpa Aerasi adalah $8,91 \mathrm{Kg} / \mathrm{m}^{3}$.
\end{abstract}

Kata Kunci : Aerasi, Cirata, KJA, Polikultur.

\begin{abstract}
Floating Net Cage (KJA) is the method for aquaculture activities in public waters such as Cirata reservoir. The Common problems faced by fish farmers KJA in Cirata is the low concentration of dissolved oxygen in these locations, so it would directly affect the lives of fish. It would cause a low rate of growth which would reduce productivity. The object of this research is productivity pomfret and tilapia in polyculture KJA. This study was conducted over 10 weeks. The experimental method with two treatments, KJA dengan aerasi and KJA tanpa aerasi. There were dissolved oxygen (D), free ammonia (NH3), temperature, $\mathrm{pH}$ and weight of fish messured parameters. Average DO concentration in the aeration KJA 8.26\% higher than non aeration KJA. Based on the results of $t$ test analysis, productivity aeration KJA provides the highest yield compared to non aeration KJA. The average of aeration KJA productivity are $11.47 \mathrm{Kg} / \mathrm{m}^{3}$, while the non aeration $\mathrm{KJA}$ is $8.91 \mathrm{Kg} / \mathrm{m}^{3}$
\end{abstract}

Keywords : Aeration, Cirata, Floating net cage, Cirata. 
Herman Hamdani : Kajian Peningkatan Produktivitas Polikultur Pada Karamba Jaring Apung di Waduk Cirata dengan Pemanfaatan Teknologi Aerasi

\section{Pendahuluan}

Waduk Cirata merupakan salah satu waduk yang dibangun di aliran Sungai Citarum. Waduk Cirata terletak di tiga kabupaten, yaitu Kabupaten Bandung Barat, Kabupaten Cianjur dan Kabupaten Purwakarta. Waduk yang dibangun pada tahun 1988 ini berada pada ketinggian $221 \mathrm{~m}$ dari permukaan laut, mempunyai wilayah luas tangkap-an air 603.200 Ha, luas 6200 Ha, Kedalaman maksimum Waduk Cirata ini hingga 100 $\mathrm{m}$. Secara administratif lokasi Waduk merupakan perairan umum yang sangat potensial dikembangkan untuk kegiatan budidaya ikan. Teknologi budidaya ikan dalam karamba jaring apung (KJA) saat ini sudah berkembang dengan pesat di beberapa danau dan waduk terutama di Jawa Barat. Kegiatan budidaya ikan dalam KJA di Waduk Cirata pada umumnya sudah berupa polikultur atau memelihara dua jenis ikan atau lebih dalam wadah yang sama.

Pemeliharaan dua jenis ikan secara bersamaan dalam satu wadah dibutuhkan teknik dan manajemen tertentu, baik dalam hal pemilihan jenis ikan, pengelolaan pakan, maupun pengelolaan kualitas air, mengingat masing-masing jenis ikan memiliki karakteristik yang berbeda-beda. Dengan memperhatikan karakteristik semua jenis ikan yang dipelihara dan mencukupi semua kebutuhannya, diharapkan produktivitas budidaya dapat dimaksimalkan. Saat ini di Waduk Cirata jenis ikan yang biasa dipolikulturkan diantaranya adalah ikan bawal air tawar (Colossoma macropomum) dan Ikan Nila (Oreochromis niloticus).

Faktor lain yang perlu mendapatkan perhatian dalam budidaya polikultur adalah pengelolaan kualitas air terutama pemenuhan kebutuhan oksigen terlarut. Waduk Cirata saat ini sudah berada dalam kondisi yang kurang optimal atau berada di bawah batas kebutuhan ikan-ikan budidaya, apalagi jika budidaya dilakukan secara polikultur. Untuk itu diperlukan upaya-upaya tertentu, termasuk introduksi teknologi aerasi guna meningkatkan konsentrasi oksigen terlarut agar mencapai konsentrasi yang optimal untuk budidaya. Penelitian ini diharapkan menghasilkan suatu sistem aerasi KJA, yang membuat kandungan oksigen terlarutnya mencukupi kebutuhan seluruh ikan yang dibudidayakan dan tersedia sepanjang hari serta dapat diterima pembudidaya dalam kegiatan budidaya ikan dalam KJA.

\section{Bahan dan Metode}

\section{Lokasi dan Waktu}

Penelitian dilaksanakan di karamba jaring apung Waduk Cirata, di daerah Jawa Barat Kabupaten Cianjur selama 10 minggu pada tahun 2015. Petak-petak KJA yang dijadikan satuan percobaan merupakan milik mitra.

\section{Alat dan Bahan}

Adapun alat-alat yang digunakan dalam penelitian ini adalah sebagai berikut : Petak KJA sebanyak 2 buah, berukuran $(7 \times 7 \times$ $2,5) \mathrm{m}^{3}$ yaitu petak yang diaerasi dan petak yang tidak diaerasi, Aerator sebagai pemasok oksigen $(8400 \mathrm{~L} / \mathrm{jam})$, selang aerasi, batu aerasi, DO meter, $\mathrm{pH}$ meter, Thermometer, Amonia test kit, tali tambang dan timbangan. Bahan yang digunakan dalam penelitian ini diantaranya adalah Ikan bawal dan ikan nila ukuran 5-10 cm masing-masing 30.000 ekor sebagai ikan uji dan pakan ikan sebanyak 4 ton.

\section{Metode Penelitian dan Analisis Data}

Penelitian ini dilakukan secara experimental dengan 2 perlakuan yaitu : KJA yang menggunakan Aerasi dan KJA Non Aerasi dengan ulangan temporal selama 10 minggu. Parameter yang diuji dalam penelitian terdiri dari parameter ikan dan parameter kualitas air (Tabel 1). Data pertumbuhan dan oksigen terlarut yang diperoleh dianalisis dengan menggunakan uji $t$ berpasangan dengan $f$ hitung 5\% artinya membandingkan satu perlakuan dengan perlakuan lainnya untuk mengetahui perlakuan mana yang lebih baik di antara keduanya Data-data yang diperoleh dianalisis secara deskriptif, membandingkan langsung hasil dari 2 perlakuan dengan baku mutu air untuk budidaya berdasarkan peraturan pemerintah Republik Indonesia nomor 82 tahun 2001. 
Tabel 1. Parameter yang dianalisis

Table 1. Parameters Analyzed

\begin{tabular}{|c|c|c|c|c|}
\hline No. & Parameter & Metode analisis & Alat & Lokasi \\
\hline 1 & Oksigen Terlarut(DO) & Potensio metri & DO meter & Insitu \\
\hline 2 & Amonia bebas $\left(\mathrm{NH}_{3}\right)$ & Colori metri & DC1600 colori meter & Insitu \\
\hline 3 & Suhu & Potensio metri & Thermometer & Insitu \\
\hline 4 & $p H$ & Potensio metri & $\mathrm{pH}$ meter & Insitu \\
\hline 5 & Bobot dan Produktivitas ikan & Gravimetri & Neraca $0,01 \mathrm{~g}$ & Insitu \\
\hline
\end{tabular}

\section{Hasil dan Pembahasan}

Oksigen Terlarut (DO)

Berdasarkan data hasil pengukuran konsentrasi oksigen di karamba jaring apung, Karamba tanpa aerasi memiliki DO yang lebih rendah sekitar 8,26\% jika dibandingkan dengan karamba yang menggunakan aerasi.
Konsentrasi DO rata-rata karamba yang menggunakan aerasi sekitar $6,2 \mathrm{mg} / \mathrm{l}$, sedangkang karamba tanpa aerasi $5,7 \mathrm{~m} / 1$. Perbedaan konsentrasi DO dipengaruhi oleh aerator yang terus menyala di karamba yang menggunakan aerasi selama 8 jam dan (Gambar 1) memperlihatkan rata-rata konsentrasi oksigen perminggu selama penelitian.

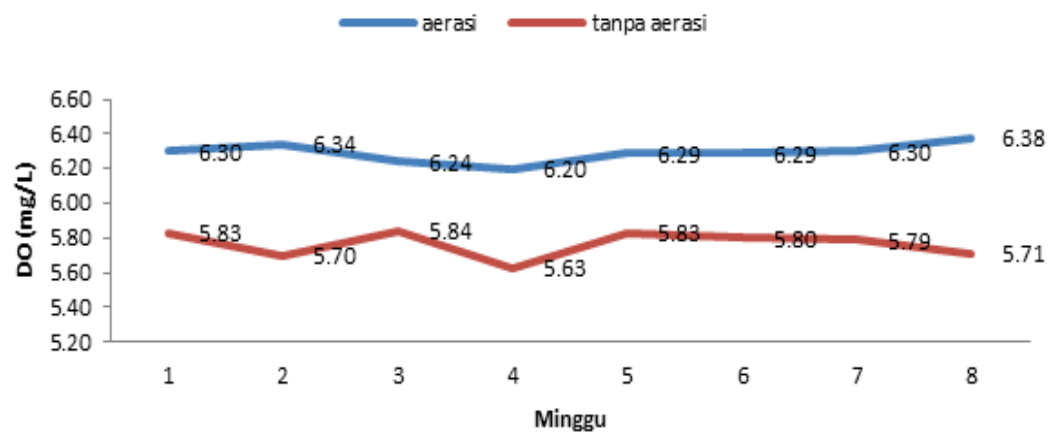

Gambar 1. Fluktuasi Konsentrasi DO Selama Penelitian

Figure 1. Fluctuations of DO concentration Over Research

Konsentrasi oksigen pada penelitian menunjukan adanya perbedaan karamba dengan aerasi dan tanpa aerasi. Tingginya DO pada karamba yang menggunakan perlakuan aerasi maka akan ikut meningkatkan produktivitas ikan. Konsentrasi oksigen terlarut erat kaitannya dengan padat penebaran ikan, semakin tinggi padat tebar ikan maka akan semakin banyak oksigen yang dibutuhkan ikan karena tingginya kebutuhan oksigen untuk proses metabolisme, pengelolaan makanan, aktivitas pergerakan dan proses respirasi (Boyd, 1990). Ketersediaan oksigen merupakan salah satu penentu konsumsi pakan ikan (nafsu makan), karena oksigen merupakan salah satu unsur yang diperlukan untuk mengubah makanan menjadi energi, saat nafsu makan berkurang, asupan pakan ke dalam tubuh ikan akan berkurang sehingga energi untuk pertumbuhan ikan tidak terpenuhi, sehingga hal ini juga yang menyebabkan lambatnya pertumbuhan ikan pada DO air yang rendah(Boyd, 1982).

Permasalahan bagi kehidupan diperairan selalu menuntut akan tercukupinya oksigen yang terlarut di dalam air. Jika kondisi ini tidak terpenuhi, maka akan menyebabkan keadaan anaerobik. Keadaan ini tidak diinginkan karena dapat menyebabkan kematian pada biota perairan, warna hitam pada air dan menimbulkan bau (Rao,1979). Peningkatan kadar DO perlu dilakukan dalam pemeliharaan ikan khususnya di KJA untuk menjaga kelangsungan hidup ikan. Menurut Mahyuddin (2011) untuk pemeliharan ikan 
bawal kadar DO minimal $3 \mathrm{mg} / \mathrm{l}$. Menurut Said (2006) Do yang dibutuhkan untuk kelangsungan hidup ikan nila berada pada kisaran $3,4-6,7 \mathrm{mg} / 1$.

\section{Amonia Bebas}

Hasil penelitian menunjukkan tidak adanya perbedaan kandungan amonia antara keramba yang menggunakan aerasi dengan keramba tanpa menggunakan aerasi. yaitu berkisar antara $0-0,003 \mathrm{mg} / \mathrm{L}$. Kadar amonia total pada sistem polikultur ikan bawal dan ikan nila selama penelitian masih dalam kondisi aman, hal ini sesuai dengan kriteria Molleda 2007, bahwa ikan air tawar masih toleran terhadap total amonia sampai $1,0 \mathrm{mg} / \mathrm{L}$.

Amonia (NH3) merupakan hasil utama dari penguraian protein yang merupakan racun bagi ikan, karena itu kandungan $\mathrm{NH}_{3}$ perairan dianjurkan tidak lebih dari $1 \mathrm{ppm}$ (Djokosetiyanto et al., 2006). Sumber amonia di perairan adalah hasil pemecahan nitrogen (protein dan urea) dan nitrogen anorganik yang terdapat dalam tanah dan air (Effendi, 2003). Amonia yang merupakan hasil eksresi utama ikan jika berada pada konsentrasi tinggi, akan memperlambat laju pertumbuhan ikan (Rahardjo et al.,2010). Hasil penelitian menunjukkan tidak adanya perbedaan kandungan amonia antara keramba yang menggunakan aerasi dengan keramba tanpa menggunakan aerasi.

\section{Suhu}

Berdasarkan hasil penelitian, nilai suhu berkisar antara $25,46-29,17{ }^{\circ} \mathrm{C}$ pada karamba dengan aerasi) dan $28,80-29,16^{\circ} \mathrm{C}$ pada karamba tanpa aerasi. Suhu pada media menggunakan aerasi dan tanpa aerasi tidak memperlihatkan perbedaan yang sangat jauh. Berikut ini merupakan Grafik nilai suhu selama penelitian (Gambar 2).

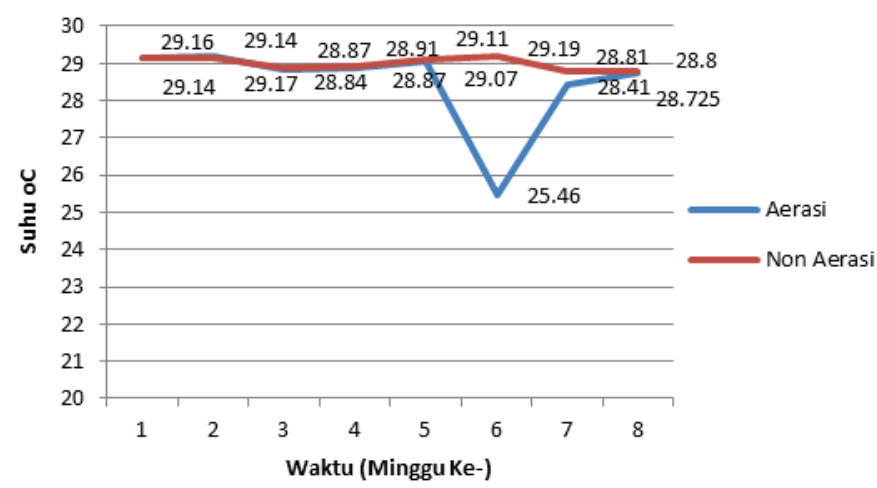

Gambar 2. Konsentrasi Suhu Selama Penelitian

Figure 2. Concentration of Temperature Over Research

Menurut Mahyuddin (2011), suhu optimum untuk budidaya ikan bawal berkisar antara $25^{\circ} \mathrm{C}-30^{\circ} \mathrm{C}$. Kondisi suhu pada penelitian ini berada pada kisaran optimum. Pada kondisi suhu yang optimum pertumbuhan ikan menjadi maksimal. Ketika pada suhu yang optimum aktivitas enzim yang terlibat dalam proses katabolisme dan anabolisme meningkat. Meningkatnya katabolisme dan anabolisme memacu laju metabolisme, sehingga kadar metabolit darah menjadi berkurang. Akibatnya derajat lapar ikan menjadi meningkat yang dapat memacu aktivitas makan dan tingkatnya konsumsi pakan juga meningkatnya. Meningkatnya tingkat konsumsi pakan akan menyebabkan pertumbuhan ikan menjadi maksimal (Affandi, 2003).

Pada kondisi suhu yang optimum ini pula aktivitas enzim pencernaan meningkat sehingga mempercepat laju pencernaan dan penyerapan. Akibatnya laju pengosongan lambung menjadi cepat membuat ikan aktif mencari makan atau aktivitas makan ikan meningkat, tingkat konsumsi pakan juga meningkat. Pakan yang dikonsumsi ikan akan menyediakan energi yang sebagian besar digunakan untuk metabolisme yang meliputi energi untuk hidup pokok, energi untuk aktivitas, energi untuk pencernaan makanan dan energi untuk pertumbuhan, sedangkan sebagian lainnya dikeluarkan dalam bentuk 
feses dan bahan ekskresi lainnya (Kurnia, 2002). Sebaliknya pada kondisi suhu yang abnormal (tinggi atau rendah) akan menyebabkan enzim-enzim yang terlibat dalam proses metabolisme maupun pencernaan dan penyerapan menjadi menurun. Menurunnya laju metabolisme, dan laju pencernaan akan mengakibatkan kadar metabolit darah meningkat dan laju pengosongan lambung menjadi lambat. Sehingga aktivitas makan dan tingkat konsumsi pakan ikan menurun. Hal ini dapat menyebabkan pertumbuhan ikan terhambat.

\section{Derajat Keasaman (pH)}

Nilai H (Power of Hydrogen) adalah nilai ion hidrogen $\left(\mathrm{H}^{+}\right)$di dalam air. Air dengan kandungan ion $\mathrm{H}^{+}$banyak akan bersifat asam, dan sebaliknya akan bersifat basa (alkali). Berikut ini merupakan grafik konsentrasi $\mathrm{pH}$ selama penelitian (Gambar 3). Berdasarkan grafik menunjukkan bahwa nila $\mathrm{pH}$ pada masing-masing perlakuan tidak menunjukkan perbedaan yang mencolok, kisaran $\mathrm{pH}$ selama penelititan sebesar 6,54-6,93 pada karamba yang menggunakan aerasi) dan 6,65-7 pada karamba tanpa aerasi.

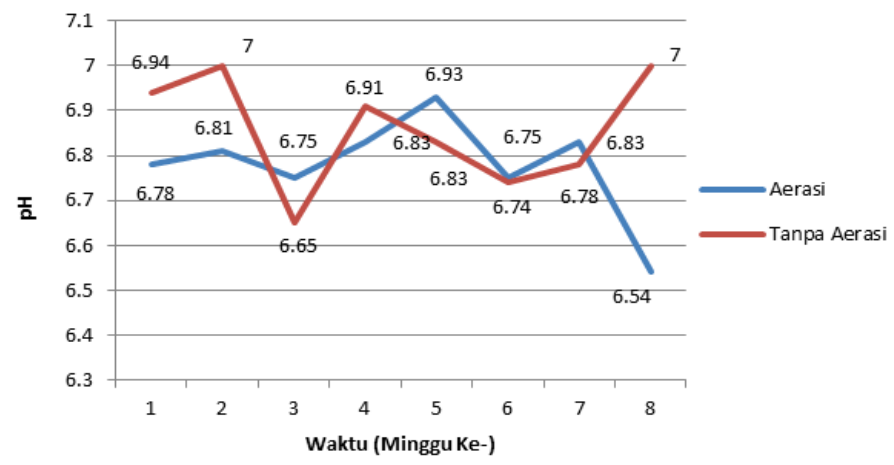

Gambar 3 Konsentrasi pH Selama Penelitian

Figure 3 Concentration $\mathrm{pH}$ Over Research

Kisaran $\mathrm{pH}$ pada penelitian ini masuk dalam kondisi optimum untuk ikan. Menurut Molleda 2007, kondisi optimal pH untuk ikan berkisar antara $6,5-8$, oleh karena itu kondisi $\mathrm{pH}$ selama penelitian masih berada pada kisaran yang normal. Nilai $\mathrm{pH}$ di atas 9,2 atau kurang dari 4,8 dapat menyebabkan kematian pada ikan. Nilai $\mathrm{pH}$ yang tinggi terjadi pada perairan dengan kandungan alga yang tinggi, sehingga proses fotosintesis membutuhkan banyak $\mathrm{CO}_{2}$.

\section{Bobot dan Produktivitas Ikan}

Pertambahan bobot ikan nila sejalan dengan pertambahan ikan bawal pada masing-masing perlakuan. Hasil analisis statistik menunjukan bahwa bobot akhir ikan nila pada perlakuan non aerasi berbeda nyata dengan bobot akhir ikan nila pada perlakuan aerasi. Perlakuan menggunakan aerasi menghasilkan pertambahan bobot yang lebih tinggi dibandingkan dengan tanpa menggunakan aerasi. Biomassa ikan dilihat dengan cara membandingkan rata-rata bobot akhir penelitian. Pada perlakuan tanpa menggunakan aerasi lebih rendah dibandingkan dengan menggunakan aerasi. Berikut ini merupakan grafik rata-rata bobot akhir ikan bawal dan ikan nila selama penelitian (Gambar 4). 
Herman Hamdani : Kajian Peningkatan Produktivitas Polikultur Pada Karamba Jaring Apung di Waduk Cirata dengan Pemanfaatan Teknologi Aerasi
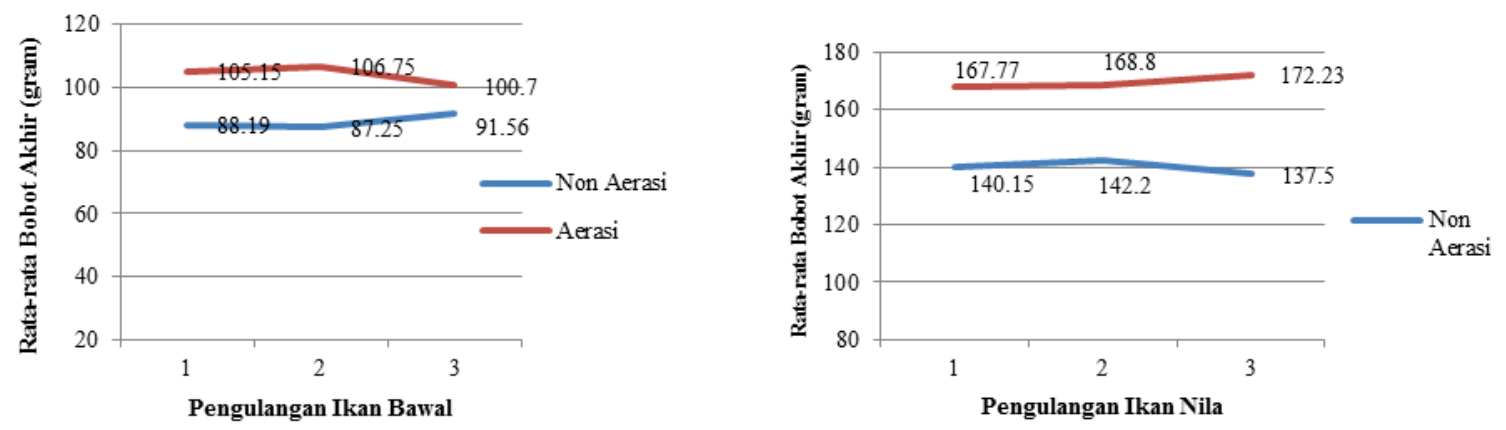

Gambar 4. Rata-rata Bobot akhir ikan Uji

Figure 4. Average weight of Fish on the final Test

Berdasarkan hasil analisis uji t, produktivitas KJA dengan menggunakan teknologi aerasi memberikan hasil tertinggi dibandingkan dengan tanpa menggunakan aerasi. Hal ini dapat terlihat dari bobot akhir pada masing-masing KJA per satuan luas volume petak di akhir penelitian. Produkivitas KJA dengan menggunakan aerasi yaitu $11,47 \mathrm{~kg} / \mathrm{m} 2$, artinya pembudidaya ikan polikultur dengan teknologi aerasi akan mendapatkan $11,47 \mathrm{~kg}$ total panen dari setiap $1,00 \mathrm{~m} 3$ luasan volume yang dimilikinya. Hal ini lebih besar dibandingkan tanpa menggunakan aerasi yang hanya mendapatkan $8,91 \mathrm{~kg} / \mathrm{m} 3$ dari setiap 1,00 m3 luasan KJA. Berikut ini merupakan tabel produktivitas KJA pada masing-masing perlakuan selama penelitian.

Tabel 2. Produktivitas KJA Selama Penelitian

Table 2. Productivity of KJA Over Research

\begin{tabular}{ccc}
\hline \multirow{2}{*}{ No. } & \multicolumn{2}{c}{ Produktivitas KJA $\left(\mathrm{Kg} / \mathrm{m}^{3}\right)$} \\
\cline { 2 - 3 } & KJA Aerasi & KJA Non Aerasi \\
\hline 1. & 11,41 & 8,80 \\
2. & 11,57 & 9,02 \\
3. & 11,42 & 8,91 \\
Rata-rata & 11,47 & 8,91 \\
\hline
\end{tabular}

Berdasarkan hasil penelitian polikultur ikan bawal dan ikan nila pada KJA terdapat hubungan antara penggunaan aerasi dengan pertambahan bobot ikan. Pemberian aerasi pada kolam KJA menghasilkan pertambahan bobot ikan bawal yang tinggi dibandingkan dengan perlakuan tanpa menggunakan aerasi. Hasil analisis statistik menunjukan bahwa bobot akhir ikan bawal pada perlakuan non aerasi berbeda nyata dengan bobot akhir ikan bawal dengan perlakuan aerasi. Pertambahan bobot ikan nila sejalan dengan pertambahan ikan bawal pada masing-masing perlakuan. Hasil analisis statistik menunjukan bahwa bobot akhir ikan nila pada perlakuan non aerasi berbeda nyata dengan bobot akhir ikan nila pada perlakuan aerasi. Perlakuan menggunakan aerasi menghasilkan pertambahan bobot yang lebih tinggi dibandingkan dengan tanpa menggunakan aerasi.

Rendahnya pertambahan bobot ikan bawal dan ikan nila disebabkan respon ikan terhadap pakan yang dipengaruhi oleh kandungan oksigen terlarut pada KJA. Menurut Milstein dan Ana (1992) pada sistem polikultur dengan kombinasi spesies yang tepat dan seimbang, ikan dapat memanfaatkan pakan secara efisien apabila sinergis dengan lingkungan media budidaya diantaranya adalah kondisi oksigen terlarut, suhu, dan $\mathrm{pH}$. Penggunaan teknologi aerasi pada KJA memberikan dampak yang positif terhadap kadar oksigen terlarut pada media budidaya yang selanjutnya akan berpengaruh terhadap respon ikan terhadap pakan yang baik sehingga dapat meningkatkan pertambahan bobot ikan. Pada perlakuan tanpa menggunakan aerasi kandungan oksigen terlarut pada KJA lebih rendah, hal 
ini berpengaruh terhadap rendahnya respon ikan terhadap pakan sehingga pertambahan bobot ikan menjadi lebih rendah.

Menurut Effendie (1997), oksigen terlarut merupakan parameter yang sangat essensial bagi fungsi metabolisme termasuk pencernaan dan asimilasi makanan serta pertumbuhan. Kebutuhan oksigen terlarut pada ikan tergantung pada umur, spesies, ukuran, dan padat penebaran. Optimasi kandungan oksigen terlaurut pada kegiatan budidaya melalui penambahan aerasi pada sistem budidaya KJA dapat meningkatkan produksi ikan dan efisiensi pakan karena ikan mempunyai respon pakan yang baik. Selain itu pertambahan bobot ikan dipengaruhi oleh rasio padat tebar ikan pada sistem budidaya polikultur. Menurut Sisckey dan Baldwin (2011) budidaya polikultur dengan kepadatan tinggi menyebabkan adanya interaksi negatif antar spesies. Pada rasio padat tebar yang tinggi akan terjadi pengeluaran energi yang berlebih karena ikan sama-sama mempertahankan diri dalam memperebutkan ruang gerak dan pemanfaatan pakan, sehingga energi yang seharusnya untuk pertumbuhan akan berkurang.

Ada banyak definisi tentang produktivitas yang telah dikemukakan, David Richardo yang pertama kali mencetuskan konsep produktivitas dengan menggunakan konsep keluaran (out put) dan masukan (in put) sebagai elemen utama dengan konsep inti bagaimana keluaran akan terpengaruh bila besaran masukan berubah (Ravianto, 1986). Jumlah produk ikan yang dihasilkan masingmasing usaha budidaya ikan dalam KJA sangat dipengaruhi oleh penggunaan faktorfaktor produksinya. Jumlah produksi rata-rata yang dihasilkan oleh petani ikan merupakan salah satu cara untuk membandingkan tingkat produktivitas budidaya ikan dalam KJA. Volume KJA yang dimaksud dalam penelitian ini adalah panjang, lebar, dan tinggi unit. Hal ini tergantung pada jumlah unit yang dimiliki oleh masing-masing petani ikan. Untuk menghitung produktivitas volume KJA yaitu dengan cara membagi output $(\mathrm{kg})$ bobot ikan ketika panen dengan luas volumer $\mathrm{kja}\left(\mathrm{m}^{3}\right)$.

Berdasarkan hasil analisis uji t, produktivitas KJA dengan menggunakan teknologi aerasi memberikan hasil tertinggi dibandingkan dengan tanpa menggunakan aerasi. Hal ini dapat terlihat dari bobot akhir pada masing-masing KJA per satuan luas volume petak di akhir penelitian. Produkivitas KJA dengan menggunakan aerasi yaitu $11,47 \mathrm{~kg} / \mathrm{m}^{2}, \quad$ artinya pembudidaya ikan polikultur dengan teknologi aerasi akan mendapatkan $11,47 \mathrm{~kg}$ total panen dari setiap $1,00 \mathrm{~m}^{3}$ luasan volume yang dimilikinya. Hal ini lebih besar dibandingkan tanpa menggunakan aerasi yang hanya mendapatkan $8,91 \mathrm{~kg} / \mathrm{m}^{3}$ dari setiap $1,00 \mathrm{~m}^{3}$ luasan KJA. Adanya perbedaan yang nyata pada produktivitas luasan KJA ini diduga dengan pemberian teknologi aerasi meningkatkan pertumbuhan ikan, sehingga dengan dengan luasan KJA yang sama dapat memberikan total panen yang berbeda.

Faktor produksi lainnya yang diperlukan untuk usaha budidaya ikan jaring terapung antara lain adalah pakan. Pakan merupakan faktor produksi yang paling menentukan besarnya volume produksi (Ramos, 2007). Seperti pada usaha budidaya intensif yang lain, usaha budidaya ikan dalam KJA juga mengandalkan makanan buatan sebagai sumber pakan utama ikan yang dipelihara. Pemberian teknologi aerasi pada KJA memberikan pengaruh yang positif yaitu adanya penambahan oksigen terlarut media budidaya, hal ini akan mempengaruihi respon ikan terhadap pakan. Oleh karena itu produktivitas pakan akan lebih tinggi pada perlakuan dengan menggunakan teknolgi aerasi karena memiliki efisiensi pakan yang baik dibandingkan dengan perlakuan tanpa menggunakan teknologi aerasi.

\section{Kesimpulan}

Berdasarkan hasil penelitian produktivitas polikultur ikan bawal dan ikan nila dalam KJA yang diintervensi dengan teknologi aerasi bertenaga surya menghasilkan produktivitas yang lebih tinggi yaitu 11,47 $\mathrm{kg} / \mathrm{m}^{3}$ dibandingkan dengan tanpa teknologi aerasi sebesar $8,91 \mathrm{~kg} / \mathrm{m}^{3}$. Produktivitas meningkat karena kandungan DO pada KJA dengan teknologi aerasi bertenaga surya lebih tinggi 8,26\% jika dibandingkan dengan KJA tanpa teknologi aerasi. 


\section{Ucapan Terimakasih}

Ucapan terima kasih yang sebesar-besarnya disampaikan kepada seluruh pihak yang terlibat dalam penelitian ini dan BLU atas dukungan dana penelitian.

\section{Daftar pustaka}

Affandi, R dan U.M. Tang., 2003. Fisiologi Hewan Air. Unri Press. 279 hal.

Boyd, 1990. Water quality management in Alabama in aquaculture experiment stations ponds for aquaculture. Brimingham Publishing, Alabama.

Djokosetiyanto, D., A. Sunarna dan Widanarni. 2006. Perubahan Ammonia (NH3-N), Nitrit (NO2-N) dan Nitrat (NO3-N) pada media Pemeliharaan Ikan Nila Merah (Oreochromis sp.) di dalam Sistem Resirkulasi. Jurnal Akuakultur Indonesia 5(1): 13-20.

Effendie, M. I. 1997. Biologi Perikanan. Yayasan Pustaka Nusantara, Bogor.

Effendie, M. I. 2003. Metode Biologi Perikanan. Gramedia Pustaka Utama, Jakarta.

Kurnia, A., 2002. Pengaruh Kadar Protein dan Rasio Energi Pakan Berbeda Terhadap Efisiensi Pakan dan Pertumbuhan Benih Ikan Baung (Mystus nemurus CV). Tesis. Program Pascasarjana. Institut Pertanian Bogor.

Mahyuddin. 2011. Usaha pembenihan ikan bawal diberbagai wadah. Jakarta. Penebar Swadaya.
Molleda, M. I. 2007. Water quality in recirculating aquaculture system for arctic charr (Salvelinus alpinus L.) Culture. División de Cultivos Marinos, Centro de Investigaciones Pesqueras (CIP) 5ta Ave y 246. Barlovento, Santa Fe, Ciudad de la Habana, Cuba.

Milstein dan Ana.1992. Ecological Aspects of Fish Species Interactions on Polyculture Fish \& Aquaculture Research Station. Dor M.P. 30820 Hof HaCarmel, Israel Hydrobiologia 231: 177.

Rahardjo, M.F., Sjafei DS, Affandi R, Sulistiono, dan Hutabarat J. 2010. Iktiology. CV. Lubuk Agung, Bandung. $396 \mathrm{hlm}$

Ramos, C. L. 2007. Aquaponic Farm Update : BoFish, Guadalajara,Mexico. Aquaponics Journal, 47: 38-39.

Ravianto, J. 1986. Produktivitas dan Keluarga. Lembaga Sarana Informasi Usaha dan Produktivitas Nasional. Jakarta.

Said, Azwar. 2006. Pengaruh Komposisi Hydrilla verticillata dan Lemna minor Sebagai Pakan Harian Terhadap Pertumbuhan dan Sintasan Ikan NIla Merah (Oreochromis niloticus X Oreochromis mossambicus) dalam Keramba Jaring Apung di Perairan Umum DAS Musi. J. Prosiding Seminar Nasional Ikan IV.

Siskey, M dan R. Baldwin. 2011. Integrated Multi-Trophic Aquaculture. University of New Hamshpire Sea Grant Tech Paper 797. 